\title{
High spatial resolution aerosol retrievals used for daily particulate matter monitoring over Po valley, northern Italy
}

\author{
B. Arvani ${ }^{1}$, R. B. Pierce ${ }^{2}$, A. I. Lyapustin ${ }^{3}$, Y. Wang $^{4}$, G. Ghermandi ${ }^{1}$, and \\ S. Teggi ${ }^{1}$
}

${ }^{1}$ Dipartimento di Ingegneria Enzo Ferrari, Università di Modena e Reggio Emilia, via P. Vivarelli 10, 41125 Modena, Italy

${ }^{2}$ NOAA/NESDIS Advanced Satellite Products Branch, 1225 W. Dayton Street, Madison, WI 53706, USA

${ }^{3}$ NASA Goddard Space Flight Center, code 613, Greenbelt, Maryland 20771, USA

${ }^{4}$ University of Maryland, Baltimore County, 1000 Hilltop Circle, Baltimore, MD, USA

Received: 25 November 2014 - Accepted: 11 December 2014 - Published: 7 January 2015

Correspondence to: B. Arvani (barbara.arvani@unimore.it)

Published by Copernicus Publications on behalf of the European Geosciences Union.

\section{High spatial \\ resolution aerosol retrievals \\ B. Arvani et al.}

\section{Title Page}

\section{Abstract}

Introduction

Conclusions

References

Tables

Figures

14

4

Back

Full Screen / Esc

Printer-friendly Version

Interactive Discussion 


\section{Abstract}

The Moderate Resolution Imaging Spectroradiometer (MODIS) Collection 5.1 Aerosol Optical Depth (AOD) data retrieved at $0.55 \mu \mathrm{m}$ with spatial resolution of $10 \mathrm{~km}$ (MYD04) and the new $1 \mathrm{~km}$ Multi-Angle Implementation of Atmospheric Correction (MAIAC) al5 gorithm from MODIS is investigated in this work. We focus on evaluating the ability of these two products to characterize the spatial distribution of aerosols within urban areas. This is done through the comparison with $\mathrm{PM}_{10}$ measurements from 126 of the Italian Regional Agency for Environmental Protection (ARPA) ground monitoring stations during 2012. The Po Valley area (northern Italy) was chosen as the study domain since urban air pollution is one of the most important concerns in this region. Population and industrial activities are located within a large number of urban areas within the valley. We find that the annual correlations between $\mathrm{PM}_{10}$ and AOD are $R^{2}=0.90$ and $R^{2}=0.62$ for MYD04 and for MAIAC respectively. When the depth of the planetary boundary layer (PBL) is used to normalize the AOD, we find a significant improvement in the PM-AOD correlation. The introduction of the PBL information is needed for AOD to capture the seasonal cycle of the observed $\mathrm{PM}_{10}$ over the Po valley and significantly improves the PM vs. AOD relationship, leading to a correlation of $R^{2}=0.98$ for both retrievals when they are normalized by the PBL depth. The results show that the normalized MAIAC retrieval provides a higher resolution depiction of the AOD within the Po retrieval for the same days and locations.

\section{Introduction}

Particulate matter (PM), also defined as atmospheric aerosol, is one of the major pollutants studied and monitored sense it affects air quality in urban and rural areas world-
ACPD

$15,123-155,2015$

\section{High spatial \\ resolution aerosol retrievals \\ B. Arvani et al.}

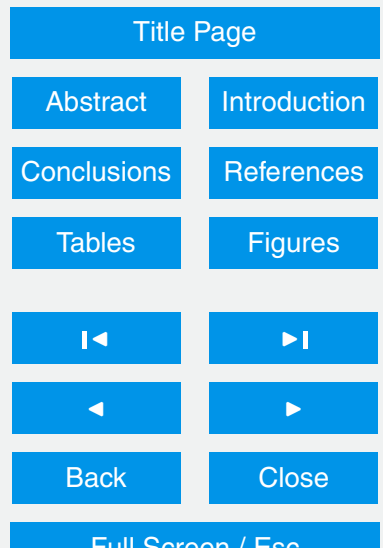

Full Screen / Esc

Printer-friendly Version

Interactive Discussion 
air for different periods of time. The sources of the atmospheric aerosols include both natural activity, such as fire, sea salt, volcanic eruptions and windblown dust, and anthropogenic activity, such as combustion, traffic and industrial emissions. PM with aerodynamic diameter of $10 \mu \mathrm{m}$ or less $\left(\mathrm{PM}_{10}\right)$ leads to serious human health effects. They 5 can be inhaled into the respiratory system and so cause respiratory lung diseases and even premature death (Forastiere et al., 2005; Brunekreef and Forsberg, 2005; Pope et al., 2004). At local scale, urban pollution plays a significant role on issues related to health due to high urban population densities. Prior to the twentieth century, most urban air pollution problems arose from the burning of wood, cool and other raw ma10 terials without any emission controls. Such burning resulted in significant increases in health issues related to urban pollution (Jacobson, 2012).

The Po Valley, in the northern part of Italy, is the area with the most severe air pollution problems in the country as it is the largest industrial, trading and agricultural area with a high population density (Bigi et al., 2012). As shown by the MODIS true color image on 16 March 2012 (Fig. 1), a region of visible haze due to strong aerosol pollution is evident throughout the Po Valley. The pollution problems that affect the Po Valley are not only related to the presence of highly urbanized and industrial centers. In fact, the presence of the Alpine mountain chain at the North and West sides of the valley, and the Apennines to the South, act as a barrier to winds blowing from Northern Europe and the Mediterranean, favoring stagnation conditions and accumulation of pollutants (Mazzola et al., 2010; Putaud et al., 2004, 2010). Because of this, monitoring in this area requires data with high spatial resolution to better characterize the spatial variability of pollution within the Po Valley.

Due to health problems associated with urban air pollution, many environmental protection agencies have been developing capabilities for continuous monitoring and assessment of air pollution from ground-based stations and for improving sampling techniques. These ground-based measurements are necessary to guide studies of possible ways to reduce the air pollution problems. Yet, ground-based observations represent point measurements and do not have the necessary coverage to characterize the
ACPD

$15,123-155,2015$

\section{High spatial \\ resolution aerosol retrievals \\ B. Arvani et al.}

Title Page

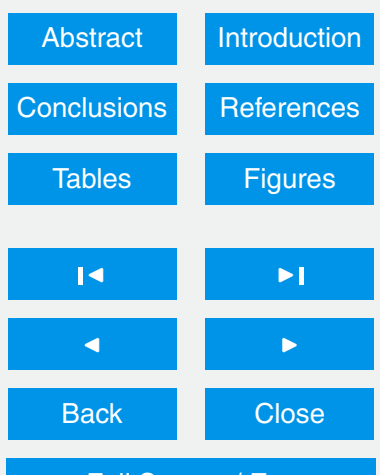

Full Screen / Esc

Printer-friendly Version

Interactive Discussion 
regional distribution of aerosols in the atmosphere. Moreover, the PM ground-based stations only provide information at the surface. The development of satellite remote sensing aerosol products since the launch of the Moderate resolution Imaging Spectroradiometer (MODIS) onboard the NASA Terra and Aqua satellites has permitted the 5 exploration of new research techniques for monitoring global air quality (Fishman et al., 2008; Gupta et al., 2006). This alternative approach for air quality monitoring provides air quality data where the ground-based measurements are not available. The potential for using space-based sensors for the air quality monitoring was demonstrated using Aerosol Optical Depth (AOD) data in combination with the PM ground-based stations 10 (Chu et al., 2003; Wang and Christopher, 2003). The use of MODIS aerosol products to investigate air pollution was demonstrated both in research fields (van Donkelaar et al., 2006; Tian and Chen, 2010; Gupta and Christopher, 2008) and for operational applications (Al-Saadi et al., 2005). But, the satellite AOD quantifies the presence of aerosols in an atmospheric column, while the surface PM mass concentration is needed for the 15 assessment of air quality health impacts: it is not obvious what the relationship between these two quantities is for a particular region. Hoff and Christopher (2009) provide a detailed review of the literature on how satellite remote sensing provides an alternative way to monitor the surface PM mass concentration. As they point out, correlations between ground measurements and optical thickness are actively used and investigated. However, their correlation is often not high enough for AOD retrievals to be operationally incorporated in air quality monitoring procedures. The MODIS standard aerosol product spatial resolution is appropriate for application on regional to global scale. However, its nominal resolution at nadir $(10 \mathrm{~km})$ may be too coarse to resolve urban scale processes. Therefore, alternative aerosol retrieval algorithms have been developed using the MODIS data in order to produce a finer high-spatial resolution product. The MODIS NASA research team recently released a new MODIS product: MODIS Collection 6, which includes a global aerosol product at nominal $3 \mathrm{~km}$, in addition to the standard MYD04 at $10 \mathrm{~km}$ (Remer et al., 2013; Munchak et al., 2013; Livingston et al., 2014). Recently, the Multi-Angle Implementation of Atmospheric Correction (MAIAC) algorithm

\section{ACPD}

$15,123-155,2015$

High spatial

resolution aerosol retrievals

B. Arvani et al.

Title Page

Abstract

Introduction

Conclusions

References

Tables

Figures

14

4

Back

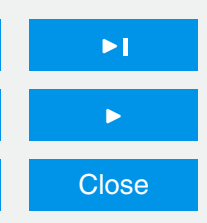

Full Screen / Esc

Printer-friendly Version

Interactive Discussion 
was developed for MODIS (Lyapustin et al., 2011a-c, 2012). The MAIAC algorithm performs a simultaneous retrieval of surface Bidirectional Reflection Distribution Function (BRDF) and aerosol properties at a resolution of $1 \mathrm{~km}$, and represents an interesting alternative for characterizing spatial variability of aerosol within polluted and industrial urban areas (Chudnovsky et al., 2013a, b; Emili et al., 2011; Hu et al., 2014).

In the current study we extend the preliminary analysis of Arvani et al. (2013) by using the MODIS Collection $5.110 \mathrm{~km}$ and the MAIAC $1 \mathrm{~km}$ resolution retrievals to analyze the relationship between $\mathrm{PM}_{10}$ and AOD within the Po Valley for an entire year (2012). We start with a direct comparison between MYD04 and MAIAC AOD retrievals and 10 the surface $\mathrm{PM}_{10}$ measurements. Then, we introduce an additional factor, the depth of the planetary boundary layer, to better characterize the seasonal variability of the particular matter over the Po Valley and improve the PM-AOD relationship. Finally, we investigate the impact of neighboring pixels and co-location radius on the correlation.

\section{Data and methods}

15 The region of interest, Po Valley in northern Italy, shown in Fig. 1, covers an area of approximately $40-50^{\circ} \mathrm{N}$ and $5-15^{\circ} \mathrm{E}$. The Po Valley is divided into four administrative divisions (regions) from west to east, Piemonte, Lombardia, Emilia Romagna and Veneto. Although the study area is small, it is possible to identify specific features for each of the four administrative regions. Piemonte is characterized by major urban centers and is heavily industrialized, including the capital city of Turin. Turin has one of the main industrial centers in Italy. Most of the Italian Regional Agency for Environmental Protection (ARPA) network stations within the Piemonte region are located near the Alps. Lombardia is the most populated region. It also has major industrial sites, including the capital city of Milan. The Emilia Romagna region, similar to Piemonte, is characterized by major urban centers. Some of the ARPA sites within this region are located close to the Apennine mountain chain to the south, and near the coast of the Adriatic Sea to the east. There are only a few ARPA stations within the Veneto region.

\section{ACPD}

$15,123-155,2015$

\section{High spatial \\ resolution aerosol retrievals \\ B. Arvani et al.}

\section{Title Page}

Abstract

Introduction

Conclusions

References

Tables

Figures

14

4

Back

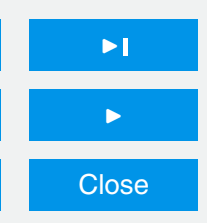

Full Screen / Esc

Printer-friendly Version

Interactive Discussion 


\subsection{Ground-level concentration of $\mathrm{PM}_{10}$}

Twenty-four hour average $\mathrm{PM}_{10}$, mass concentration in $\mu \mathrm{g} \mathrm{m}^{-3}$, was considered for 126 air quality monitoring stations within the ARPA network during the year 2012: Piemonte (27 stations), Lombardia (59 stations), Emilia Romagna (37 stations) and Veneto (3 5 stations). The distribution of ground stations, and location within the Po Valley is highlighted in Fig. 2. Each regional ARPA network has a unique set of measurements with different uncertainties. This non-uniformity may affect the regional correlations. In particular, in ARPA Piemonte and Veneto $\mathrm{PM}_{10}$ is measured using a Beta Attenuation Monitor (BAM) with an accuracy of $2 \%$. In ARPA Lombardia TEOM, TEOM-FDMS (Tapered Element Oscillating Micro-balance - Filter Dynamics Measurement System), or BAM are used, with an accuracy of $\pm 2.5 \mu \mathrm{g} \mathrm{m}^{-3}$. In ARPA Emilia Romagna, $\mathrm{PM}_{10}$ data have been collected by the beta attenuator SWAM 5A RL by FAI Instruments with an uncertainty lower than $\pm 10 \%$. All information related to the ARPA's stations and instrumentation are available at the ARPA web sites of their respective regions, mentioned 15 above.

\subsection{Satellite data}

In the present work, we use the standard MODIS Aqua Collection 5.1 (MYD04) aerosol product. This product has a nominal spatial resolution of $10 \mathrm{~km}$ at nadir, and increases by roughly four-fold at the edges of the swath. The MODIS AOD algorithm uses mul-

tispectral observed radiance and pre-computed look-up tables to retrieve AOD over ocean and land (Remer et al., 2005, 2006). The recently developed MAIAC aerosol retrieval algorithm (Lyapustin et al., 2011a, b) is also considered. This algorithm is part of MODIS Aqua Land retrieval and is provided over the land only. It is retrieved at a finer spatial resolution $(1 \mathrm{~km})$, making simultaneous use of BRDF parameters. This 25 is accomplished by using the time series of MODIS measurements and simultaneous processing of groups of pixels. The MAIAC algorithm guarantees that the number of measurements exceeds the number of unknowns, a necessary condition for solving an
ACPD

15, 123-155, 2015

\section{High spatial \\ resolution aerosol retrievals \\ B. Arvani et al.}

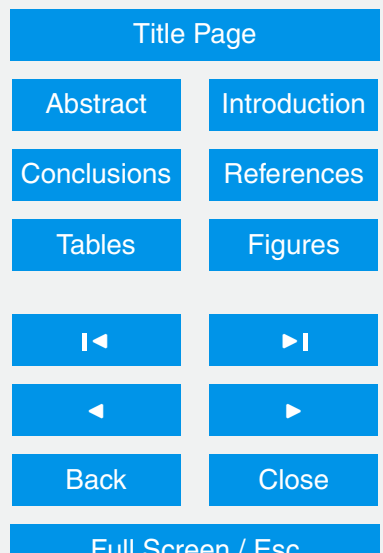

Full Screen / Esc

Printer-friendly Version

Interactive Discussion 
inverse problem without empirical assumptions, which are commonly used in current operational algorithms. The MAIAC time series approach also provides coverage at multiple (15) view angles for every surface grid cell, which is required for the BRDF retrievals from MODIS data. Moreover, MAIAC incorporates a Cloud Mask (CM) algo5 rithm based on spatio-temporal analysis which augments traditional pixel-level cloud detection techniques (Lyapustin et al., 2008). In Fig. 3, a comparison between MODIS standard and MAIAC aerosol retrieval results between is shown. As immediately evident, the higher resolution MAIAC retrieval shows substantial spatial variability which is not captured by the standard $10 \mathrm{~km}$ retrieval.

10 The MODIS Collection 5.1 retrieval has already been cloud filtered and is used without additional quality control. On the contrary, the new aerosol retrieval algorithm MAIAC includes cloud and terrain in masks, incorporated into the AOD Quality Assurance (QA) parameter definition. The MAIAC Cloud Mask (CM) and the Land-Water-Snow (LWS) mask fields have been considered during the MAIAC run in order to avoid pixels 15 where clouds, water or snow are detected. As example, 16 March 2012 is shown in Fig. 4. Comparison with the MODIS (Aqua) true color image (Fig. 1), shows an extensive area of clouds to the south-west, near the coast, that are well characterized in the MAIAC CM. The snow cover over the Alpine chain in north is also well characterized by the MAIAC LWS mask.

\subsection{Satellite data and ground measurements co-location}

The MODIS Collection 5.1 aerosol product, MAIAC retrievals and surface $\mathrm{PM}_{10}$ were collocated in space and time for 2012 for each ARPA station considered. The spatial co-location of MODIS and MAIAC pixels with $\mathrm{PM}_{10}$ ground-based stations was accomplished using two different methods. The nearest neighbor method calculates the

\section{ACPD}

$15,123-155,2015$

\section{High spatial \\ resolution aerosol retrievals \\ B. Arvani et al.}

\section{Title Page}

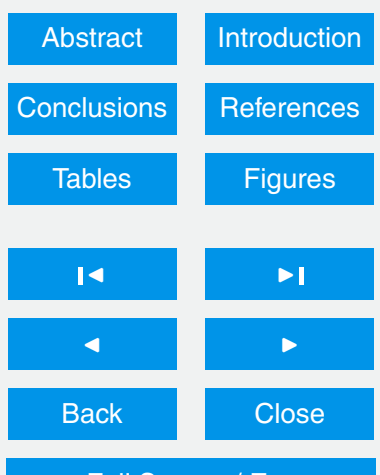

Full Screen / Esc

Printer-friendly Version

Interactive Discussion a tolerance radius of $0.20^{\circ}$ (about $20-25 \mathrm{~km}$ at the latitude of the Po Valley) for MODIS Aqua Collection 5.1, and a tolerance radius of $0.02^{\circ}$ (about 2-2.5 km) for MAIAC AOD retrieval. The second approach, labeled average as in Gupta et al. (2006) paper, uses 
the average of all pixels within a tolerance radius of $0.20^{\circ}$ and $0.02^{\circ}$ for MODIS and MAIAC respectively. For both approaches, we accounted for more than one MAIAC coincidence per $\mathrm{PM}_{10}$ station. This is due to the overlap of different Aqua orbits within the MAIAC local tiles.

\section{$5 \quad 2.4$ AOD normalization}

$\mathrm{PM}_{10}$ and $\mathrm{AOD}$ represent two different measurements of the atmospheric loading of pollutants. The $\mathrm{PM}_{10}$ is the dry mass, measured at ground level, at a specific geographic location. On the other hand, the satellite AOD represents total column aerosol loading averaged over a specific spatial area. As suggested by the literature (Gupta et al., 2006; Tsai et al., 2011), the PM-AOD correlation may be improved by considering meteorological data information or vertical distribution of aerosols. In this work, variations in the vertical distribution of aerosols are considered by introducing information on the Planetary Boundary Layer (PBL) depth. The PBL height (ZPBL) values derive from 6 hourly $0.5^{\circ} \times 0.5^{\circ}$ analysis files from the NOAA National Center for Envi15 ronmental Prediction (NCEP) Global Data Assimilation System (GDAS), downloaded from nomads.ncdc.noaa.gov. As mentioned previously, the Aerosol Optical Depth is an integration of the aerosol extinction, from the surface to the top of the atmosphere:

$\mathrm{AOD}=\int_{0}^{\mathrm{TOA}} \sigma_{0.55 \mu \mathrm{m}}^{\mathrm{ext}}(z) \mathrm{d} z$

Under the hypothesis that most of the aerosols are confined and mixed homogeneously

within the planetary boundary layer, the values of AOD normalized by PBL depth may be regarded as mean PBL extinction in $\mathrm{km}^{-1}$ and may be more representative of the surface $\mathrm{PM}_{10}$ concentration since the depth of the PBL is accounted for. The normalization was applied both for MYD04 and MAIAC retrievals.

The seasonal trend of PBL heights over Po Valley shows low values during the winter and high values during the summer (Fig. 5). This seasonal trend is reflected in the 130

\section{ACPD}

$15,123-155,2015$

\section{High spatial \\ resolution aerosol retrievals \\ B. Arvani et al.}

\section{Title Page}

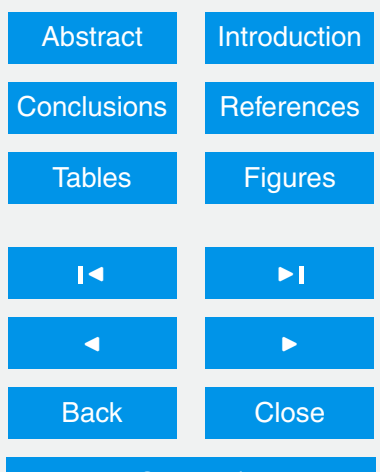

Full Screen / Esc

Printer-friendly Version

Interactive Discussion 
AOD monthly mean values normalized by PBL depth and results in higher values in the winter and fall period (Figs. 7 and 8, panels $c$ and d). The normalized MYD04 and MAIAC mean AOD values follow the PM trend throughout the whole year and shows the strong seasonal correlation between PM and PBL depths within the Po valley.

5 To verify the GDAS PBL depths we compare them to PBL depths obtained from CALIPSO measurements (Winker et al., 2003, 2009). The CALIPSO PBL depths are derived using a Haar wavelet analysis to detect boundaries in scattering ratio (i.e. a normalized backscatter) in Lidar observations that include the atmospheric boundary layer. The CALIPSO PBL heights are taken as altitude where the maximum amplitude aver10 age wavelet occurs computed over a range of Haar filter widths ranging from 0.9 to $1.65 \mathrm{~km}$ (Kuehn, R. E., 2013, personal communication). Figure 5 shows the monthly mean of the 6 hourly gridded GDAS PBL depths (green), as well as the mean of the GDAS PBL interpolated to the CALIPSO track (blue), and the CALIPSO PBL depths (red) over the Po Valley. The blue trend and the red one follow almost the same seasonal trend. The CALIPSO sampled GDAS PBL heights are comparable to the seasonal trend of the gridded GDAS PBL heights over Po Valley, except in January, where the CALIPSO sampling introduces a high bias. Comparison between the coincident CALIPSO and GDAS PBL depths shows very similar seasonal trends but CALIPSO $\mathrm{PBL}$ depths are systematically higher than the GDAS analysis.

\section{Results and discussion}

\subsection{AERONET validation}

Following Chu et al. (2002, 2003), the validation of satellite aerosol retrievals is done by comparing the satellite AOD to ground based AOD retrievals by AERONET Sun photometers (Holben et al., 1998). During 2012, three AERONET measurement sites located in Ispra, Modena and Venice (marked in black dots in Fig. 6) were available. Even though limited in number, the available AERONET stations are representative of
ACPD

$15,123-155,2015$

\section{High spatial \\ resolution aerosol retrievals \\ B. Arvani et al.}

\section{Title Page}

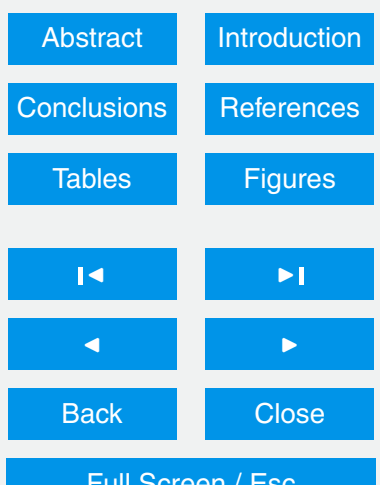

Full Screen / Esc

Printer-friendly Version

Interactive Discussion 
the Po Valley conditions: the Ispra site is located in a pre-Alpine rural region dominated by forest, Modena (the middle site) is located in an urban environment in the middle of Po Valley, and the Venise site is at the Acqua Alta Oceanographic Tower (AAOT) in the northern Adriatic Sea, 8 nautical miles off the Venice Lagoon. Due to the limited amount 5 of AERONET measurements at the Modena and Venise sites during 2012, only Ispra AERONET measurements are used for validation. Co-location of MODIS retrievals and AERONET direct Sun measurements requires at least two AERONET measurements within \pm 30 min of the MODIS overpass. The mean values of the temporal ensemble are then used in linear regression analysis. Moreover, the AERONET data are interpo10 lated in logarithm of wavelength 0.55 and $0.47 \mu \mathrm{m}$ for MYD04 and MAIAC respectively. Scatter plots for the collocated MAIAC, AERONET Level 2.0 and MYD04 AOD are shown in Fig. 6, with a determination coefficient of $R^{2}=0.84$ and $R^{2}=0.69$ for MODIS and MAIAC AOD respectively. MAIAC $(N=32)$ provides more data points than Collection $5.1(N=25)$, reflecting the higher spatial resolution of the MAIAC aerosol retrieval 15 algorithm.

\subsection{Time series analysis}

The AOD-PM 10 analysis begins with the study of the 2012 monthly mean trend of $\mathrm{PM}_{10}$ vs. AOD for both the spatial co-location approaches presented in Sect. 2.3. The results are reported in Fig. 7. The top panels show the mean daily value of $P_{10} 24 \mathrm{~h}$ mass concentration (black line), for all 126 ARPA stations, while the red dots show the monthly mean $\mathrm{PM}_{10}$ mass concentration. The AOD monthly mean values are represented on the graph by the blue and the green dots, for MYD04 and MAIAC, respectively. As immediately evident, the trends in PM and AOD are different during the winter and fall periods for both nearest-neighbor (Fig. 7a) and average (Fig. 7b) coincidence approaches. For both methods, a radius of coincidence equal to $0.02^{\circ}$ was used for MYD04 and MAIAC to allow for a more direct comparison. The disagreement is particular notable for the two last months of the year, where the PM monthly mean values increase, while AOD values decrease. The highest values of PM are recorded in this

\section{ACPD}

$15,123-155,2015$

\section{High spatial \\ resolution aerosol retrievals \\ B. Arvani et al.}

\section{Title Page}

14

4
- I 
period of the year due to the meteorological conditions that favor the buildup of nearsurface pollutants, and regional environmental protection agencies are actively trying limit air pollution problems (Mazzola et al., 2010). The same analysis was conducted considering a larger radius of coincidence and did not have significant impact on the 5 final time series result (Fig. $8 a$ and b).

\subsection{Scatter plot and bin analysis: $\mathrm{PM}_{10}$ vs. AOD relationship. Comparison of different method of coincidence}

As second step of analysis, we proceed with the calculation of the determination coefficient between daily $\mathrm{PM}_{10}$ mass concentration and AOD from both MYD04 and MAIAC to estimate quantitatively the linear relationship between the two data sets. In Sect. 2.3, two different approaches to find the spatial co-location of satellite pixel with the groundbased station have been presented, the nearest neighbor and average method.

Because of the large spread of PM and AOD values, it is more useful to derive a simple linear regression equation between $\mathrm{PM}_{10}$ mass concentration and $\mathrm{AOD}$ by dividing the $\mathrm{PM}_{10}(24 \mathrm{hrs})$ into 10 bins of $5 \mathrm{\mu g} \mathrm{m}^{-3}$ intervals and comparing them with the mean AOD within each bin. So, the final value of AOD per each $\mathrm{PM}_{10}$ bin is determined by calculating the average value of AOD between the values of $A O D$ retrieved in each class of PM. This set of ten points is reported on the scatter plot as black dots in Fig. 9, using the nearest neighbor approach. The solid red line shows the linear regression line for these two data sets. White dots refer to median values of AOD at fixed value of $P M_{10}$. Yellow symbols represent the 25th and 75th percentile (first and third quartiles) respectively in AOD for a particular $\mathrm{PM}_{10}$ bin. This simple statistical approach gives a robust estimate of the linear regression between the $\mathrm{PM}_{10}$ and satellite data (Gupta et al., 2006). The correlation between bin-averaged AOD and $\mathrm{PM}_{10}$ concentration is highest for MYD04, with $R^{2}=0.90$. The higher resolution MAIAC retrieval algorithm has a significantly lower $R^{2}$ of 0.62 . As mentioned in the previous subsection, the $\mathrm{PM}_{10}-\mathrm{AOD}$ correlation may be improved with the introduction of aerosol planetary
ACPD

$15,123-155,2015$

High spatial

resolution aerosol retrievals

B. Arvani et al.

Title Page

Abstract

Introduction

Conclusions

References

Tables

Figures

14

4

Back

Close

Full Screen / Esc

Printer-friendly Version

Interactive Discussion 
boundary layer information. Therefore, the same analysis was applied, considering the $\mathrm{PM}$ vs. AOD/ZPBL data sets. The results are summarized in Fig. 9 in the right panels $b$ and d. They show an $R^{2}$ of 0.98 for both MYD04 and MAIAC when AOD is normalized by the PBL depth. Looking closely at the results shown in Fig. 9 shows that while the $5 \mathrm{PM}-\mathrm{AOD} / \mathrm{ZPBL}$ correlation has a strong linear behavior with a slope close to 1 , this is not true for the PM-AOD correlations. The median AOD is roughly linear with respect to PM for the first five bins. After the fifth bin, the median AOD shows less variation with PM, especially from MAIAC data set. This points to a more complex relationship between $\mathrm{PM}_{10}$ and $A O D$ than represented with a linear regression for the $\mathrm{PM}_{10}$ vs. 10 AOD relationship.

Regarding to the use of the average approach, if there is at least one missing pixel within the tolerance area we set the mean AOD value equal to a missing data. This is a conservative approach since it automatically excludes all the retrievals in the neighborhood of pixels identified by the terrain and cloud masks within a fixed tolerance

area. Following this approach to determine the coincidences, the binned scatter plot results in $R^{2}=0.92$ and $R^{2}=0.76$ for MYD04 and MAIAC, respectively. If this conservative approach is not taken we find that the $R^{2}$ for the MAIAC AOD normalized by PBL depth has a much lower correlation with $\mathrm{PM}_{10}$. On the other hand, we find that the impact of neighboring missing values is less of an issue for the standard MODIS retrieval, possibly due to a more conservative cloud mask. The difference between the two approaches is shown in Fig. 10. Looking at Fig. 10a and b, or Fig. 10d and e, the $\mathrm{PM}_{10}$ ground-based sites located at the edge of the AOD retrieval map are detected as "coincidence" site in the nearest neighbor approach, while "no coincidence" in the average one. From the average coincidence results shown in Fig. 11, it is remarkable there considered. This is not surprising because of the different spatial resolution of the AOD retrieval, as better explain in Sect. 2.2.

\section{ACPD}

$15,123-155,2015$

\section{High spatial \\ resolution aerosol retrievals \\ B. Arvani et al.}

\section{Title Page}

14

4 


\subsection{Study of the impact of the radius of coincidence on $R^{2}$}

Until now, the statistical analysis has been conducted using a fixed radius of coincidence of $0.20^{\circ}$ for MYD04 and $0.02^{\circ}$ for MAIAC based on the nominal spatial resolution of the two satellite aerosol retrievals used in this work. Changing the value of the ra5 dius of coincidence will change the final number of coincidences detected and likely the final $R^{2}$ value in this statistical analysis. Therefore, this section studies the impact of changing the value of the tolerance radius on $R^{2}$ value. Figure 12 shows a comparison between $R^{2}$ and radius of coincidence in km for MYD04 and MAIAC for each method of coincidence used in this study. For the sake of clarity, the radius of coincidence was converted from degrees to kilometers assuming $1^{\circ}=111.121 \mathrm{~km}$ valid at the mean latitude of the study domain. For the standard MODIS retrieval, changing of the radius of coincidence value does not have a significant impact on $R^{2}$ value except for changing from about 2 to $5 \mathrm{~km}$ where $R^{2}$ increases from 0.78 to 0.90 . Also, the standard MODIS PM-AOD/ZPBL relationship is less sensitive to the radius of coincidence than the PM-AOD correlation. The MAIAC results, on the other hand, have completely different behavior. The nearest neighbor approach, as expected, does not depend on the radius of coincidence, and maintains a constant offset between the PM-AOD and PM-AOD/ZPBL correlations. The average approach shows a significant dependence on the radius of coincidence. The $R^{2}$ value in the average method for the PM-AOD 20 correlation is maximum (0.87) for radius equal to $12 \mathrm{~km}$, and minimum $(0.76)$ for radius equal to $2 \mathrm{~km}$. On the other hand, in the PM-AOD/ZPBL relationship, the $R^{2}$ value is roughly constant.

Figure 13 shows the direct comparison between the MYD04 and MAIAC number of coincidences $(\mathrm{N})$ and radius for both the methods of coincidence analyzed in this work. For MYD04, the number of coincidences shows a significant dependence on the radius, especially for the first three values $\left(0.02,0.05\right.$ and $\left.0.08^{\circ}\right)$ where $N$ increases rapidly when the radius threshold is increased. For larger coincidence radius, the $\mathrm{N}$ trend is roughly constant for the nearest neighbor approach and decreases for the
ACPD

$15,123-155,2015$

\section{High spatial \\ resolution aerosol retrievals \\ B. Arvani et al.}

Title Page

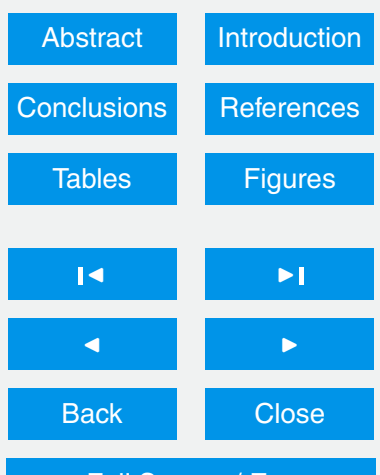

Full Screen / Esc

Printer-friendly Version

Interactive Discussion 
average approach. For MAIAC, there is a much more rapid decrease in the number of coincidences for the average approach than with MYDO4 due to the high spatial resolution of the retrieval. MAIAC shows a nearly constant $\mathrm{N}$ for the nearest neighbor approach.

Until recently, the MODIS Collection 5.1 satellite AOD data product, with $10 \mathrm{~km}$ resolution, was the main source of global satellite aerosol data used by the air quality community. The new MAIAC AOD product, at $1 \mathrm{~km}$ resolution, provides a significantly higher resolution product that may be more appropriate for urban air quality studies.

10 This paper analyzed the effect of spatial resolution on the correlation between remotely sensed AOD and ground-based $\mathrm{PM}_{10}$ concentration measurements. One year (2012) of MODIS Aqua retrievals over the Po valley domain were used.

The major findings of this study are summarized below.

1. Time series analysis of the monthly mean AOD values shows a notable disagreement with surface $\mathrm{PM}_{10}$ in the fall and winter period, days characterized by meteorological conditions that favor the buildup of near-surface pollution, for both retrievals. This disagreement is reduced by normalization of AOD by the PBL height.

2. A direct comparison between coarse MYD04 $10 \mathrm{~km}$ AOD and high-resolution MAIAC $1 \mathrm{~km}$ AOD for all collocated PM vs. AOD pairs for the same period of analysis and sites show that both retrievals have low correlations.

3. As often noted by the literature, the link between surface measurements and AOD data alone is limited and often not suitable for quantitative analysis. However, the normalization by the PBL depth significantly improves the $R^{2}$ due to seasonal changes in the PBL depth over the Po Valley. $R^{2}=0.98$ for both standard MODIS and MAIAC retrievals was obtained during 2012.

ACPD

15, 123-155, 2015

\section{High spatial \\ resolution aerosol retrievals \\ B. Arvani et al.}

\section{Title Page}

Abstract

Introduction

Conclusions

References

Tables

Figures

14

Back

$>$

Close

Full Screen / Esc

Printer-friendly Version

Interactive Discussion 
4. Analysis of changing the tolerance radius on $R^{2}$ indicates a significant impact if the average method is applied on the PM-AOD correlation for the MAIAC retrieval. The standard MODIS retrieval was found to be largely independent of the range of radii considered in this study. This may be due to a more conservative cloud mask in the standard MODIS retrieval.

The results presented in this paper show that although the MAIAC $1 \mathrm{~km}$ retrieval provides higher resolution information on aerosol optical depth within the highly industrialized Po Valley of northern Italy although the correlation between PM and AOD is worse than standard MODIS retrieval. However, if both retrievals are normalized by the 10 PBL depth, the MAIAC results are nearly identical to the coarser resolution standard MODIS retrieval. The results reported in this work were obtained but considering just one factor that may affect the relationship between the ground-based and the satellite remote-sensing measurements. Future work will focus on improving the understanding of the satellite-retrieved $A O D$ and $\mathrm{PM}_{10}$. Specifically, we intend to investigate the use 15 of higher resolution PBL estimates obtained from regional NWP over Italy (Kukkonen et al., 2012; Baldauf et al., 2011; Barthlott et al., 2010) and explore the relationship for each administrative district over Po valley separately. The aim would be to investigate if the use of finer PBL depth and satellite-retrieved AOD (MAIAC) helps to characterize the spatial variability of aerosol pollution within the Po Valley and study the impact of industrialized regions on PM vs. AOD relationships.

Acknowledgements. This research has been funded by the Italian Ministero dell'Istruzione, dell' Università e della Ricerca (Project PRIN2010-11, 2010WLNFY2). Authors are thankful to Italian agencies ARPA Emilia-Romagna, ARPA Lombardia, ARPA Piemonte and ARPA Veneto for providing ground $\mathrm{PM}_{10}$ data. The views, opinions, and findings contained in this report are those 25 of the author(s) and should not be construed as an official National Oceanic and Atmospheric Administration or US Government position, policy, or decision.

\section{ACPD}

$15,123-155,2015$

\section{High spatial \\ resolution aerosol retrievals \\ B. Arvani et al.}

\section{Title Page}

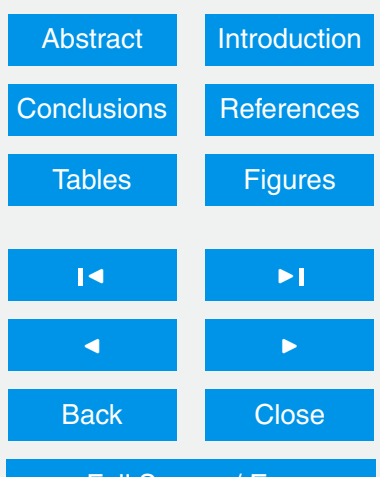

Full Screen / Esc

Printer-friendly Version

Interactive Discussion 


\section{References}

Al-Saadi, J., Szykman, J., Pierce, R. B., Kittaka, C., Neil, D., Chu, D. A., Remer, L., Gumley, L., Prins, E., Weinstock, L., MacDonald, C., Wayland, R., Dimmick, F., and Fishman, J.: Improving national air quality forecasts with satellite aerosol observations, B. Am. Meteorol. Soc., 86, 1249-1261, BAMS-86-9-1249, 2005.

Arvani, B., Pierce, R. B., Lyapustin, A. I., Wang, Y., Teggi, S., and Ghermandi, G.: Application of MAIAC high spatial resolution aerosol retrievals over Po Valley (Italy), in: Proc. SPIE 8890, Remote Sensing of Clouds and the Atmosphere XVIII; and Optics in Atmospheric Propagation and Adaptive Systems XVI, 88900P (17 October 2013), 8890-26, doi:10.1117/12.2029297, 2013.

Baldauf, M., Seifert, A., Förstner, J., Majewski, D., Raschendorfer, M., and Reinhardt, T.: Operational convective-scale numerical weather prediction with the COSMO model: description and sensitivities, Mon. Weather Rev., 139, 3887-3905, doi:10.1175/MWR-D-10- 05013.1, 2011.

15 Barthlott, C., Schipper, J. W., Kalthoff, N., Adler, B., Kottmeier, C., Blyth, A., and Mobbs, S.: Model representation of boundary-layer convergence triggering deep convection over complex terrain: a case study from COPS, Atmos. Res., 95, 172-185, 2010.

Bigi, A., Ghermandi, G., and Harrison, R. M.: Analysis of the air pollution climate at a background site in the Po valley, J. Environ. Monitor., 14, 552-563, 2012.

Brunekreef, B. and Forsberg, B.: Epidemiological evidence of effects of coarse airborne particles on health, Eur. Respir. J., 26, 309-318, 2005.

Chu, D. A., Kaufman, Y. J., Ichoku, C., Remer, L. A., Tanra, D., and Holben, B. N: Validation of MODIS aerosol optical depth retrieval over land, Geophys. Res. Lett., 29, MOD2-1-MOD2-4, 2002.

Chu, D. A., Kaufman, Y. J., Zibordi, G., Chern, J. D., Mao, J., Li, C., and Holben, B. N.: Global monitoring of air pollution over land from the Earth Observing System - Terra Moderate Resolution Imaging Spectroradiometer (MODIS), J. Geophys. Res.-Atmos., 108, 4661, doi:10.1029/2002JD003179, 2003.

Chudnovsky, A., Tang, C., Lyapustin, A., Wang, Y., Schwartz, J., and Koutrakis, P.: A critical assessment of high-resolution aerosol optical depth retrievals for fine particulate matter predictions, Atmos. Chem. Phys., 13, 10907-10917, doi:10.5194/acp-13-10907-2013, 2013 a.
ACPD

15, 123-155, 2015

\section{High spatial \\ resolution aerosol retrievals \\ B. Arvani et al.}

\section{Title Page}

Abstract Introduction

Conclusions

References

Tables

Figures

14

4

Back

Close

Full Screen / Esc

Printer-friendly Version

Interactive Discussion 
Chudnovsky, A. A., Kostinski, A., Lyapustin, A., and Koutrakis, P.: Spatial scales of pollution from variable resolution satellite imaging, Environ. Pollut., 172, 131-138, 2013b.

Emili, E., Lyapustin, A., Wang, Y., Popp, C., Korkin, S., Zebisch, M., Wunderle, S., and Petitta, M.: High spatial resolution aerosol retrieval with MAIAC: application to mountain regions,

$5 \quad$ J. Geophys. Res.-Atmos., 116, D23211, doi:10.1029/2011JD016297, 2011.

Fishman, J., Al-Saadi, J. A., Creilson, J. K., Bowman, K. W., Burrows, J. P., Richter, A., Chance, K. V., Edwards, D. P., Martin, R. V., Morris, G. A., Bradley Pierce, R., Ziemke, J. R., Schaack, T. K., and Thompson, A. M.: Remote sensing of tropospheric pollution from space, B. Am. Meteorol. Soc., 89, 805-822, 2008.

10 Forastiere, F., Stafoggia, M., Picciotto, S., Bellander, T., D'lppoliti, D., Lanki, T., von Klot, S., Nyberg, F., Paatero, P., Peters, A., Pekkanen, J., Sunyer, J., and Perucci, C. A.: A casecrossover analysis of out-of-hospital coronary deaths and air pollution in Rome, Italy, American journal of respiratory and critical care medicine, 172, 1549-1555, 2005.

Gupta, P. and Christopher, S. A.: Seven year particulate matter air quality assessment from 15 surface and satellite measurements, Atmos. Chem. Phys., 8, 3311-3324, doi:10.5194/acp8-3311-2008, 2008.

Gupta, P., Christopher, S. A., Wang, J., Gehrig, R., Lee, Y., and Kumar, N.: Satellite remote sensing of particulate matter and air quality assessment over global cities, Atmos. Environ., 40, 5880-5892, 2006.

20 Hoff, R. M. and Christopher, S. A.: Remote sensing of particulate pollution from space: have we reached the promised land?, J. Air Waste Manage., 59, 645-675, 2009.

Holben, B., Eck, T., Slutsker, I., Tanré, D., Buis, J., Setzer, A., Vermote, E., Reagan, J., Kaufman, Y., Nakajima, T., Lavenu, F., Jankowiak, I., and Smirnov, A.: AERONET - a federated instrument network and data archive for aerosol characterization, Remote Sens. Environ., $25 \quad 66,1-16,1998$.

Hu, X., Waller, L. A., Lyapustin, A., Wang, Y., Al-Hamdan, M. Z., Crosson, W. L., Estes Jr., M. G., Estes, S. M., Quattrochi, D. A., Puttaswamy, S. J., and Liu, Y.: Estimating ground-level PM $_{2.5}$ concentrations in the Southeastern United States using MAIAC AOD retrievals and a twostage model, Remote Sens. Environ., 140, 220-232, 2014.

30 Jacobson, M. Z.: Air Pollution and Global Warming: History, Science, and Solutions, Cambridge University Press, 2012.

Kukkonen, J., Olsson, T., Schultz, D. M., Baklanov, A., Klein, T., Miranda, A. I., Monteiro, A., Hirtl, M., Tarvainen, V., Boy, M., Peuch, V.-H., Poupkou, A., Kioutsioukis, I., Finardi, S.,

\section{ACPD}

$15,123-155,2015$

\section{High spatial \\ resolution aerosol retrievals \\ B. Arvani et al.}

\section{Title Page}

Abstract

Introduction

Conclusions

References

Tables

Figures

14

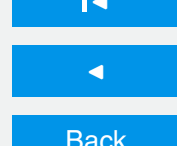

।

$>$

Back

Close

Full Screen / Esc

Printer-friendly Version

Interactive Discussion 
Sofiev, M., Sokhi, R., Lehtinen, K. E. J., Karatzas, K., San José, R., Astitha, M., Kallos, G., Schaap, M., Reimer, E., Jakobs, H., and Eben, K.: A review of operational, regionalscale, chemical weather forecasting models in Europe, Atmos. Chem. Phys., 12, 1-87, doi:10.5194/acp-12-1-2012, 2012.

5 Livingston, J. M., Redemann, J., Shinozuka, Y., Johnson, R., Russell, P. B., Zhang, Q., Mattoo, S., Remer, L., Levy, R., Munchak, L., and Ramachandran, S.: Comparison of MODIS $3 \mathrm{~km}$ and $10 \mathrm{~km}$ resolution aerosol optical depth retrievals over land with airborne sunphotometer measurements during ARCTAS summer 2008, Atmos. Chem. Phys., 14, 2015-2038, doi:10.5194/acp-14-2015-2014, 2014.

10 Lyapustin, A., Wang, Y., and Frey, R.: An automatic cloud mask algorithm based on time series of MODIS measurements, J. Geophys. Res.-Atmos., 113, D16207, doi:10.1029/2007JD009641, 2008.

Lyapustin, A., Martonchik, J., Wang, Y., Laszlo, I., and Korkin, S.: Multiangle implementation of atmospheric correction (MAIAC): 1. Radiative transfer basis and look-up tables, J. Geophys. Res.-Atmos., 116, D03210, doi:10.1029/2010JD014985, 2011a.

Lyapustin, A., Wang, Y., Hsu, C., Torres, O., Leptoukh, G., Kalashnikova, O., and Korkin, S.: Analysis of MAIAC dust aerosol retrievals from MODIS over North Africa, AAPP - Physical, Mathematical, and Natural Sciences, 89, ELS XIII Conference, Vol. 89, Supplement No 1, $2011 b$.

20

Lyapustin, A., Wang, Y., Laszlo, I., Kahn, R., Korkin, S., Remer, L., Levy, R., and Reid, J. S.: Multiangle implementation of atmospheric correction (MAIAC): 2. Aerosol algorithm, J. Geophys. Res.-Atmos., 116, D03211, doi:10.1029/2010JD014986, 2011c.

Lyapustin, A. I., Wang, Y., Laszlo, I., Hilker, T., G.Hall, F., Sellers, P. J., Tucker, C. J., and Korkin, S. V.: Multi-angle implementation of atmospheric correction for MODIS (MAIAC): 3. Atmospheric correction, Remote Sens. Environ., 127, 385-393, 2012.

Mazzola, M., Lanconelli, C., Lupi, A., Busetto, M., Vitale, V., and Tomasi, C.: Columnar aerosol optical properties in the Po Valley, Italy, from MFRSR data, J. Geophys. Res.-Atmos., 115, D17206, doi:10.1029/2009JD013310, 2010.

Munchak, L. A., Levy, R. C., Mattoo, S., Remer, L. A., Holben, B. N., Schafer, J. S., in an urban/suburban region, Atmos. Meas. Tech., 6, 1747-1759, doi:10.5194/amt-6-17472013, 2013.

\section{ACPD}

$15,123-155,2015$

\section{High spatial \\ resolution aerosol retrievals \\ B. Arvani et al.}

\section{Title Page}

Abstract

Introduction

Conclusions

References

Tables

Figures

14

4

Back

Close

Full Screen / Esc

Printer-friendly Version

Interactive Discussion 
Pope, C. A., Burnett, R. T., Thurston, G. D., Thun, M. J., Calle, E. E., Krewski, D., and Godleski, J. J.: Cardiovascular mortality and long-term exposure to particulate air pollution: epidemiological evidence of general patho-physiological pathways of disease, Circulation, 109, 71-77, 2004.

5 Putaud, J.-P., Raes, F., Dingenen, R. V., Brüggemann, E., Facchini, M.-C., Decesari, S., Fuzzi, S., Gehrig, R., Hüglin, C., Laj, P., Lorbeer, G., Maenhaut, W., Mihalopoulos, N., Müller, K., Querol, X., Rodriguez, S., Schneider, J., Spindler, G., ten Brink, H., Tørseth, K., and Wiedensohler, A.: A European aerosol phenomenology - 2: chemical characteristics of particulate matter at kerbside, urban, rural and background sites in Europe, Atmos. Environ., $10 \quad 38,2579-2595,2004$.

Putaud, J.-P., Dingenen, R. V., Alastuey, A., Bauer, H., Birmili, W., Cyrys, J., Flentje, H., Fuzzi, S., Gehrig, R., Hansson, H., Harrison, R., Herrmann, H., Hitzenberger, R., Hüglin, C., Jones, A., Kasper-Giebl, A., Kiss, G., Kousa, A., Kuhlbusch, T., Löschau, G., Maenhaut, W., Molnar, A., Moreno, T., Pekkanen, J., Perrino, C., Pitz, M., Puxbaum, H., Querol, X., Rodriguez, S., Salma, I., Schwarz, J., Smolik, J., Schneider, J., Spindler, G., ten Brink, H., Tursic, J., Viana, M., Wiedensohler, A., and Raes, F.: A European aerosol phenomenology - 3: physical and chemical characteristics of particulate matter from 60 rural, urban, and kerbside sites across Europe, Atmos. Environ., 44, 1308-1320, 2010.

Remer, L. A., Kaufman, Y. J., Tanré, D., Mattoo, S., Chu, D. A., Martins, J. V., Li, R.-R., Ichoku, C., Levy, R. C., Kleidman, R. G., Eck, T. F., Vermote, E., and Holben, B. N.: The MODIS aerosol algorithm, products, and validation, J. Atmos. Sci., 62, 947-973, 2005.

Remer, L. A., Tanre, D., Kaufman, Y. J., Levy, R., and Mattoo, S.: Algorithm for Remote Sensing of Tropospheric Aerosol from MODIS for Collection 005: Revision 2 National Aeronautics and Space Administration, Algorithm Theoretical Basis Document, available at: http://modisatmos.gsfc.nasa.gov/reference_atbd.html, 2009.

Remer, L. A., Mattoo, S., Levy, R. C., and Munchak, L. A.: MODIS $3 \mathrm{~km}$ aerosol product: algorithm and global perspective, Atmos. Meas. Tech., 6, 1829-1844, doi:10.5194/amt-6-18292013, 2013.

Tian, J. and Chen, D.: A semi-empirical model for predicting hourly ground-level fine particulate 30 matter $\left(\mathrm{PM}_{2.5}\right)$ concentration in southern Ontario from satellite remote sensing and groundbased meteorological measurements, Remote Sens. Environ., 114, 221-229, 2010.

\section{ACPD}

$15,123-155,2015$

\section{High spatial \\ resolution aerosol retrievals \\ B. Arvani et al.}

\section{Title Page}

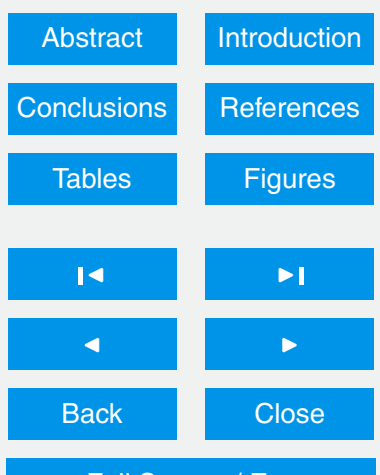

Full Screen / Esc

Printer-friendly Version

Interactive Discussion 
Tsai, T.-C., Jeng, Y.-J., Chu, D. A., Chen, J.-P., and Chang, S.-C.: Analysis of the relationship between MODIS aerosol optical depth and particulate matter from 2006 to 2008, Atmos. Environ., 45, 4777-4788, 2011.

van Donkelaar, A., Martin, R. V., and Park, R. J.: Estimating ground-level PM $_{2.5}$ using aerosol 5 optical depth determined from satellite remote sensing, J. Geophys. Res.-Atmos., 111, D21201, doi:10.1029/2005JD006996, 2006.

Wang, J. and Christopher, S. A.: Intercomparison between satellite derived aerosol optical thickness and $\mathrm{PM}_{2.5}$ mass: implications for air quality studies, Geophys. Res. Lett., 30, 2095, doi:10.1029/2003GL018174, 2003.

10 Winker, D. M., Pelon, J., and McCormick, M. P.: The CALIPSO mission: spaceborne lidas for observation of aerosols and clouds, Proc. SPIE 4893, Lidas Remote Sensind for Industry and Environment Monitoring III, doi:10.1117/12.466539, 2003

Winker, D. M., Vaughan, M. A., Omar, A., Hu, Y., Powell, K. A., Liu, Z., Hunt, W. H., and Young, S. A.: Overview of the CALIPSO Mission and CALIOP Data Processing Algorithms, J.

Atmos. Ocean. Tech., 26, 2310-2323, 2009.

\section{ACPD}

$15,123-155,2015$

\section{High spatial \\ resolution aerosol \\ retrievals \\ B. Arvani et al.}

\section{Title Page}

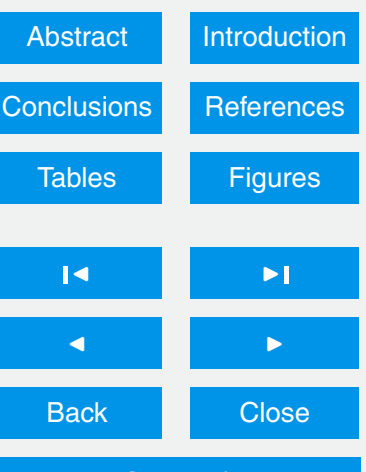

Full Screen / Esc

Printer-friendly Version

Interactive Discussion 


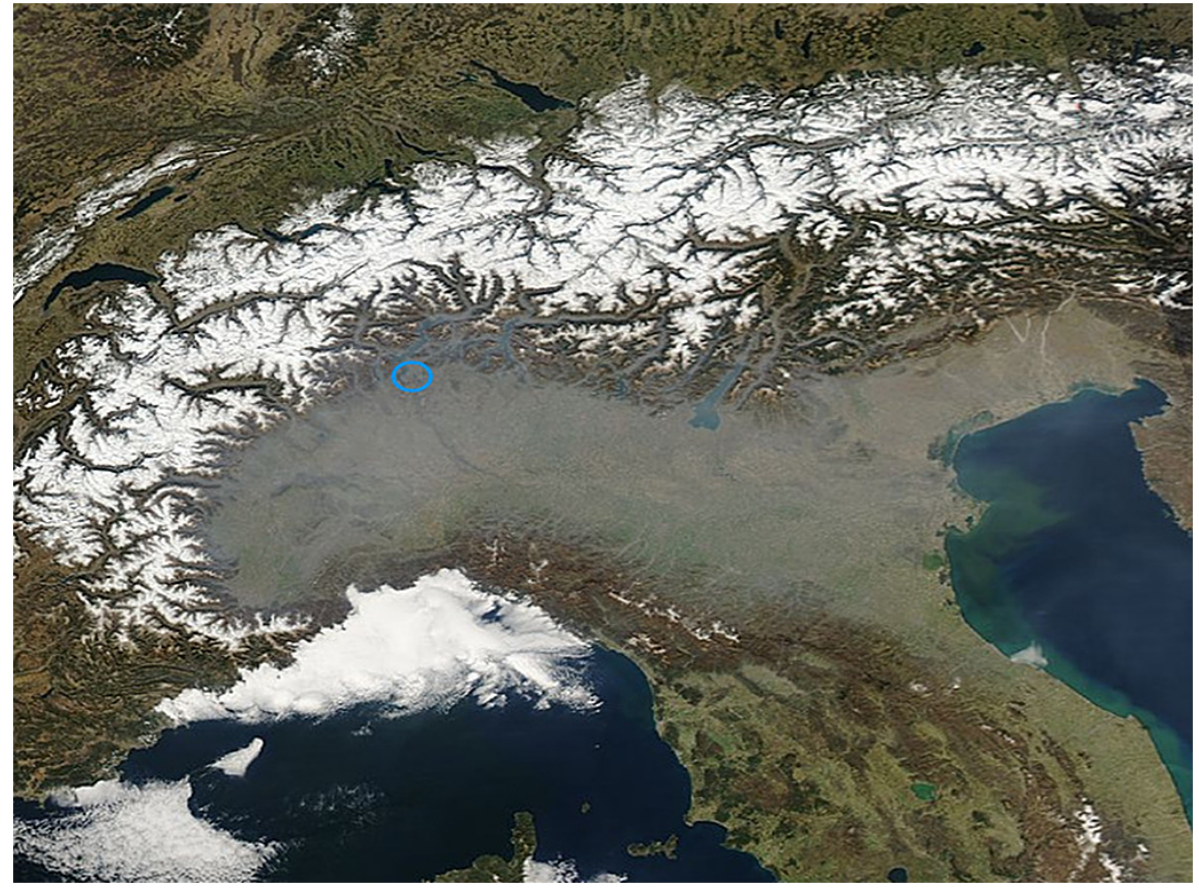

Figure 1. Geographic study domain. MODIS (Aqua) satellite True Color RGB image $-1 \mathrm{~km}, 16$ March 2012 (http://lance-modis.eosdis.nasa.gov/imagery/subsets/?project= aeronet\&subset=Ispra). The blue circle represents the geographic location of the Ispra AERONET station in the Po Valley.

\section{ACPD}

15, 123-155, 2015

\section{High spatial resolution aerosol retrievals \\ B. Arvani et al.}

Title Page
Abstract

Conclusions

\section{Tables}

$1<$

4

Back

Introduction

References

Figures

DI

$\triangleright$

Close
Printer-friendly Version

Interactive Discussion 


\section{$\mathrm{PM}_{10}$ sites over Po Valley domain}

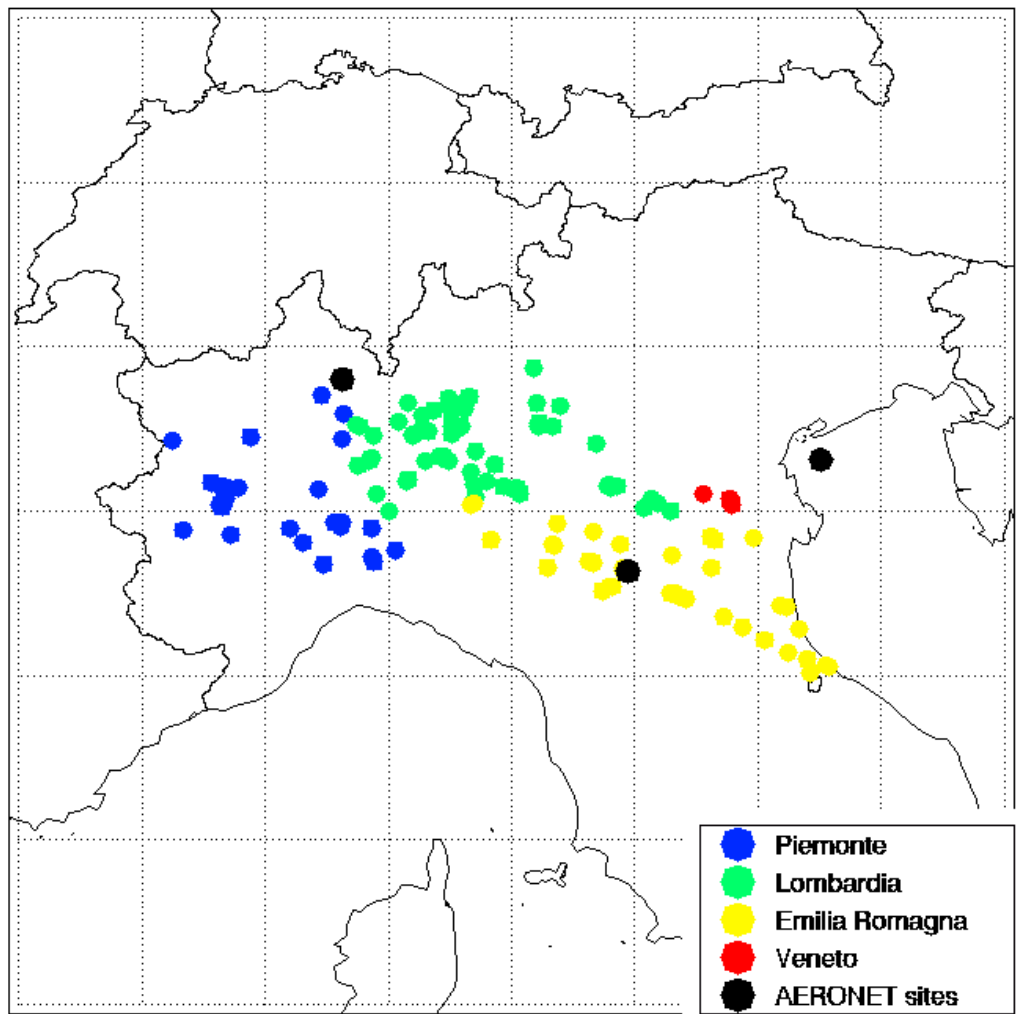

Figure 2. Geographic study domain. The dots mark locations of the ARPA PM 10 ground station sites. The dots are grouped into different color, one per each administrative division considered. The black dots are located position of AERONET stations, mentioned in Sect. 3.1.
ACPD

$15,123-155,2015$

\section{High spatial} resolution aerosol retrievals

B. Arvani et al.

\section{Title Page}

\section{Abstract}

Introduction

Conclusions

References

Tables

Figures

14

4

Back

Printer-friendly Version

Interactive Discussion 

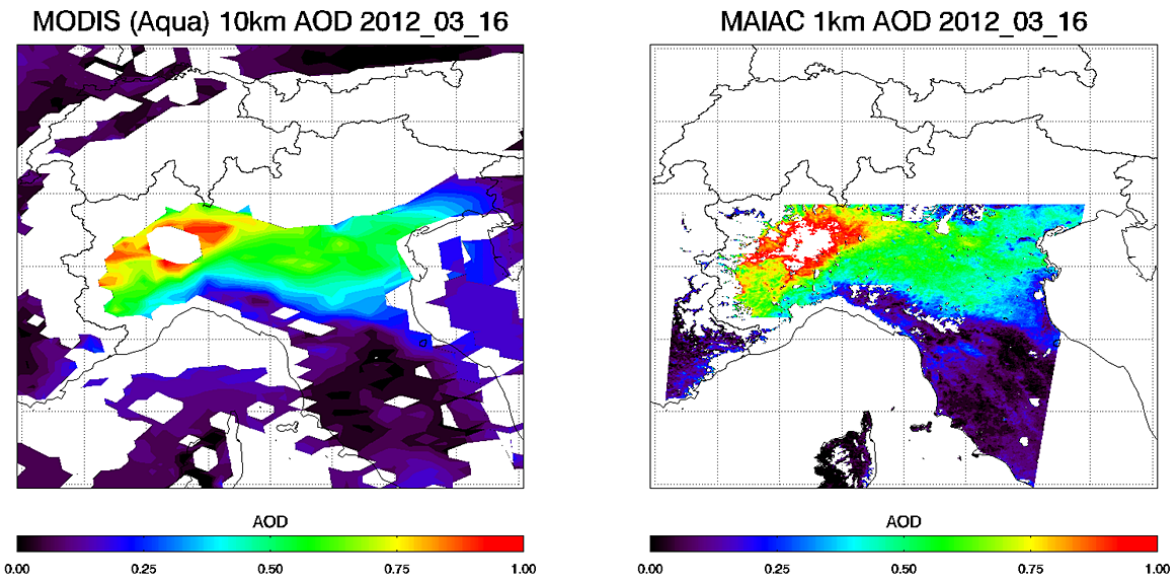

Figure 3. MYD04 $10 \mathrm{~km}$ (on the left) and MAIAC $1 \mathrm{~km}$ (on the right) AOD for 16 March 2012. As it is immediately evident, the higher resolution data reveal a substantial spatial variability of AOD which cannot be captured using a coarse $10 \mathrm{~km}$ scale.
ACPD

$15,123-155,2015$

\section{High spatial resolution aerosol retrievals}

B. Arvani et al.

\section{Title Page}

\section{Abstract}

Introduction

Conclusions

References

Tables

Figures

14

4

Back

Close

Full Screen / Esc

Printer-friendly Version

Interactive Discussion 


\section{Cloud mask 2012_03_16}
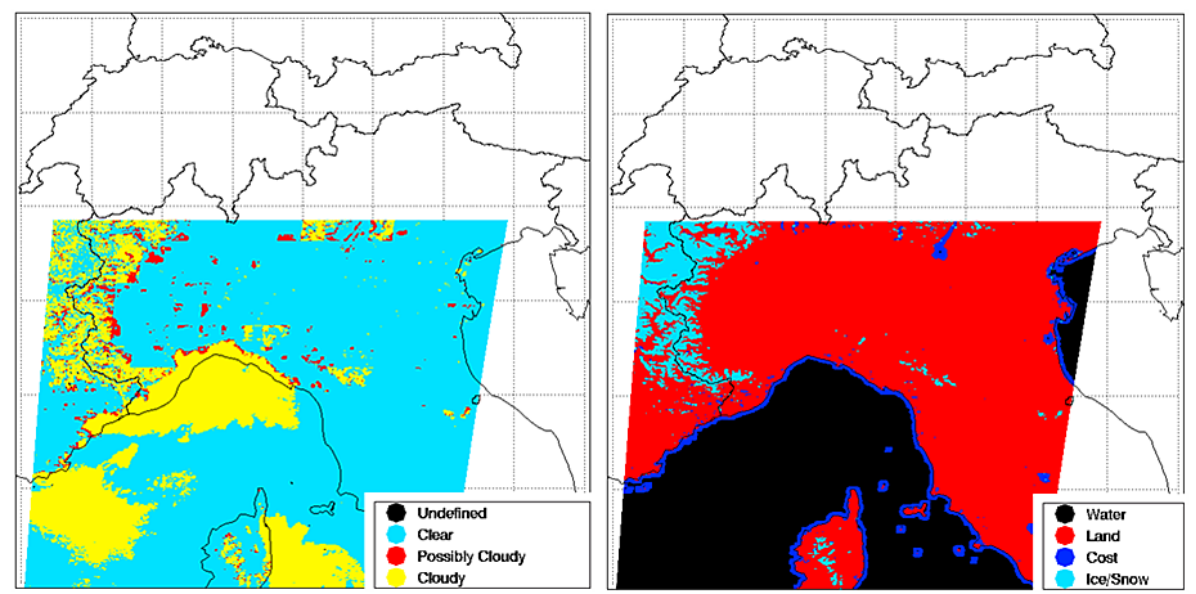

Figure 4. Understanding of the Cloud mask (CM) field and Land-Water-Snow (LWS) mask field. $\mathrm{CM}$ on the left; LWS on the right.

\section{ACPD}

$15,123-155,2015$

\section{High spatial resolution aerosol retrievals}

B. Arvani et al.

\section{Title Page}

\section{Abstract}

Introduction

Conclusions

References

Tables

Figures

14

4

Back

Close

\section{Full Screen / Esc}

Printer-friendly Version

Interactive Discussion 


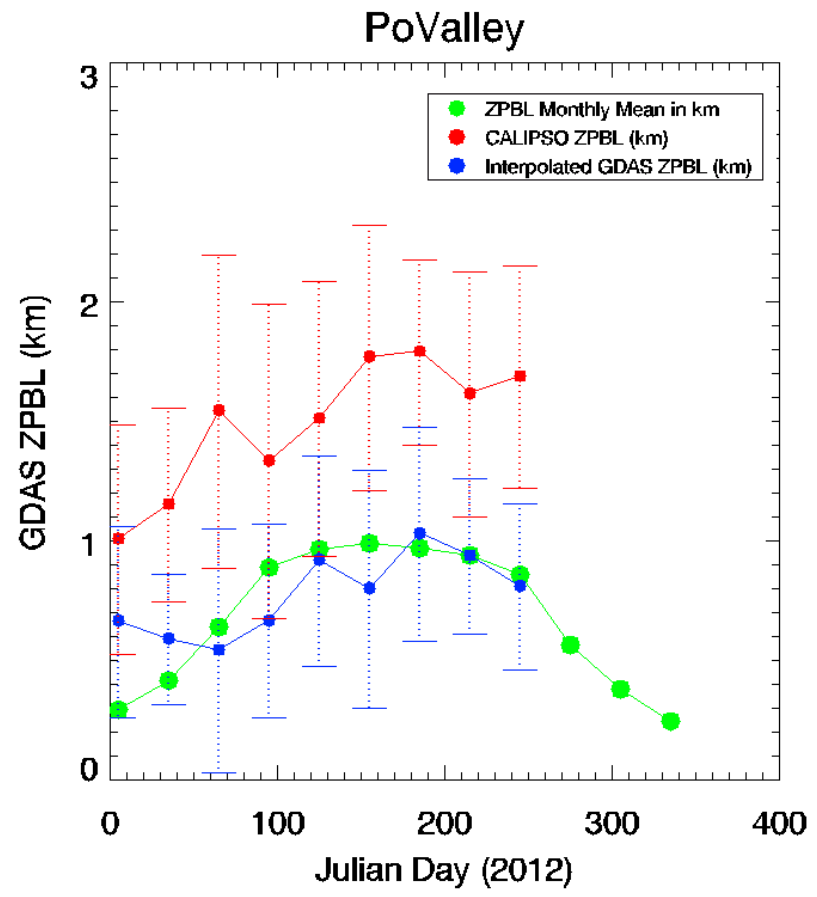

15, 123-155, 2015

\section{High spatial resolution aerosol retrievals \\ B. Arvani et al.}

\section{Title Page}

Abstract

Introduction

Conclusions

References

Tables

Figures

14

4

Back

Close

Full Screen / Esc

Printer-friendly Version

Interactive Discussion 

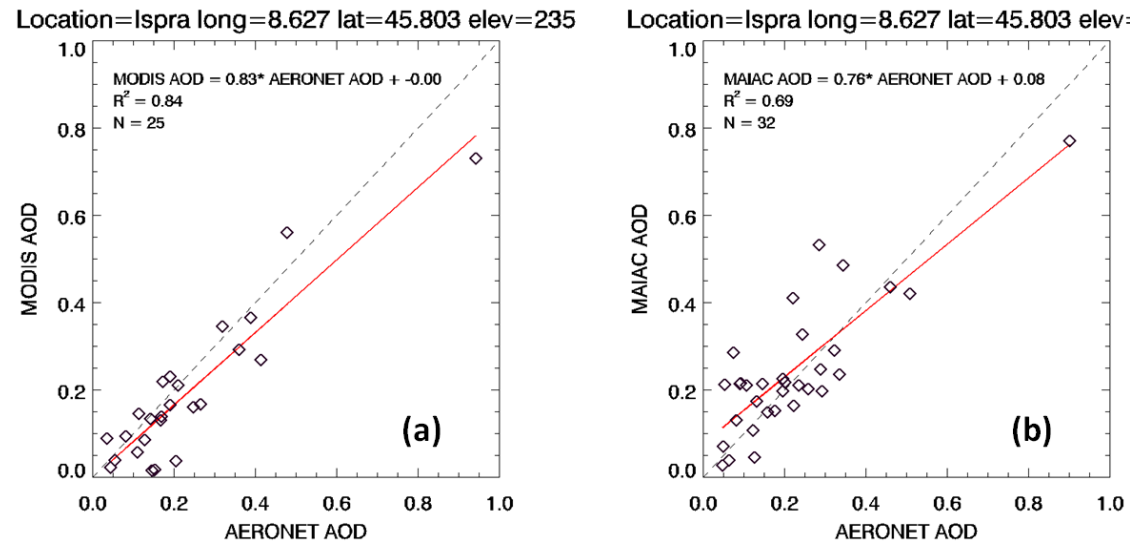

\section{ACPD}

15, 123-155, 2015

\section{High spatial resolution aerosol retrievals}

B. Arvani et al.

\section{Title Page}

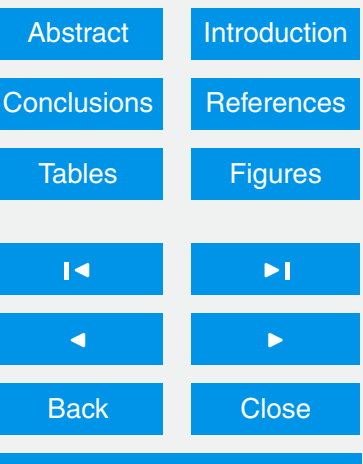

Full Screen / Esc

Printer-friendly Version

Interactive Discussion 

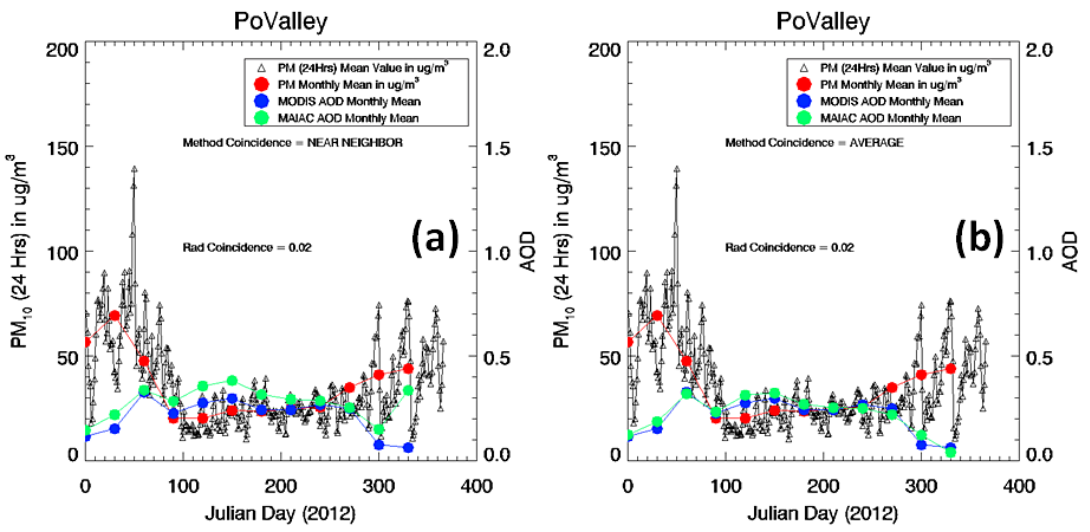

\section{ACPD}

15, 123-155, 2015
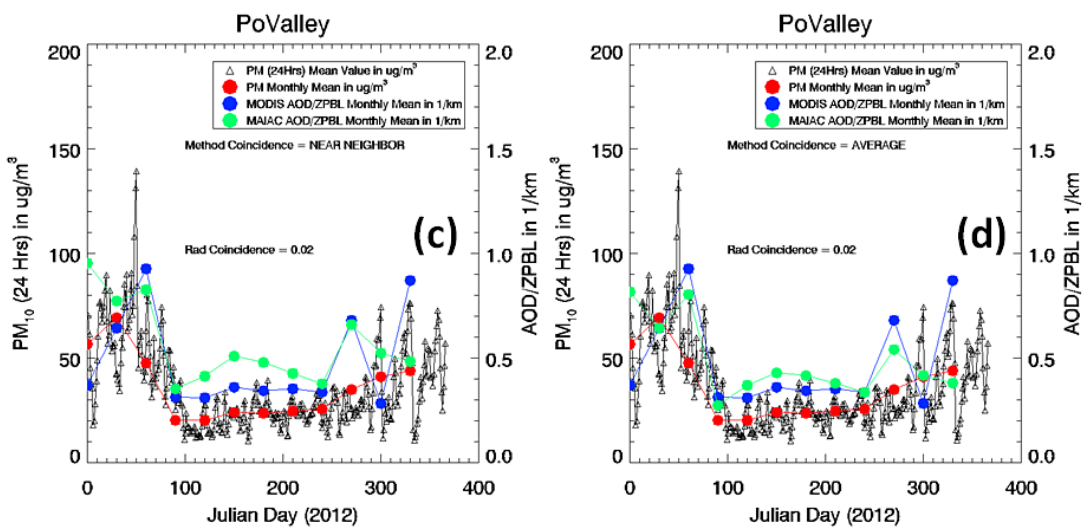

Title Page

Abstract

Introduction

Conclusions

References

Tables

Figures

14

4

Back

$>$

Close

Full Screen / Esc

Printer-friendly Version

Interactive Discussion Po valley domain. In the panels (a), (b) the relationship PM-AOD is considered, while in the panels (c), (d) are reported the results for PM-AOD/ZPBL relationship. Radius of coincidence equal to $0.02^{\circ}$. 

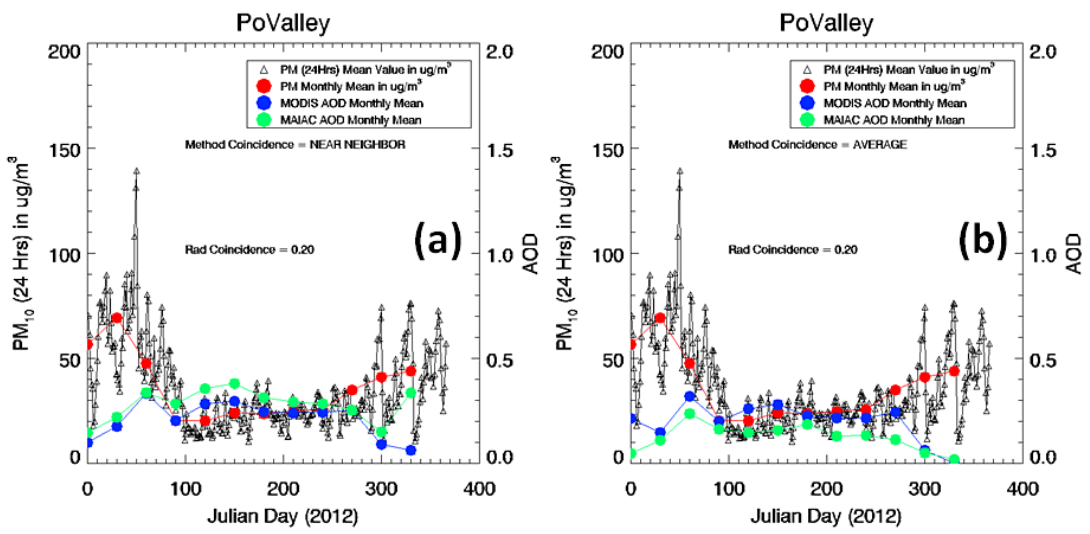

\section{ACPD}

15, 123-155, 2015
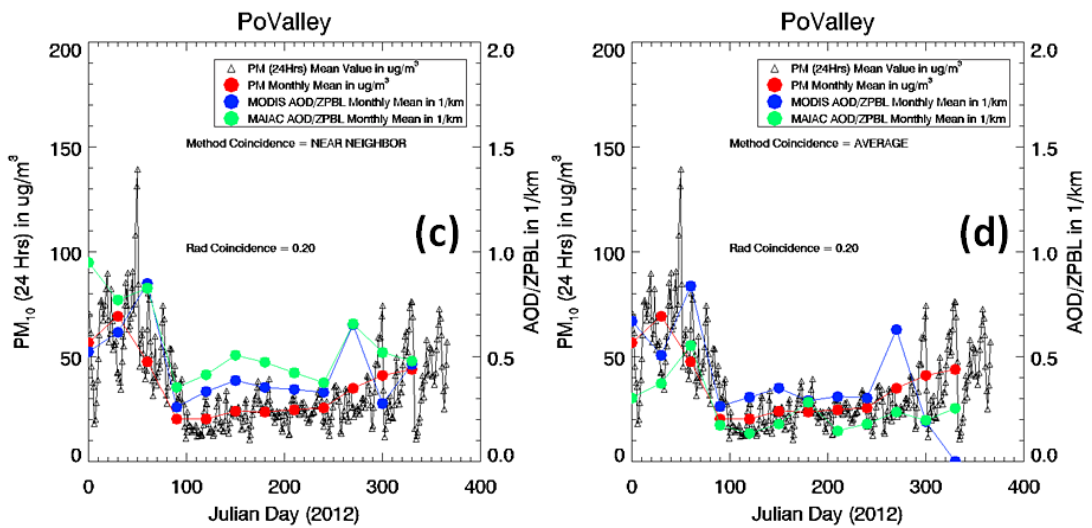

\section{Title Page}

\section{Abstract}

Introduction

Conclusions

14

4

Back

$>$

Close

Full Screen / Esc

Printer-friendly Version

Interactive Discussion Po valley domain. In the panels (a), (b) the relationship PM-AOD is considered, while in the panels (c), (d) are reported the results for PM-AOD/ZPBL relationship. Radius of coincidence equal to $0.20^{\circ}$. 

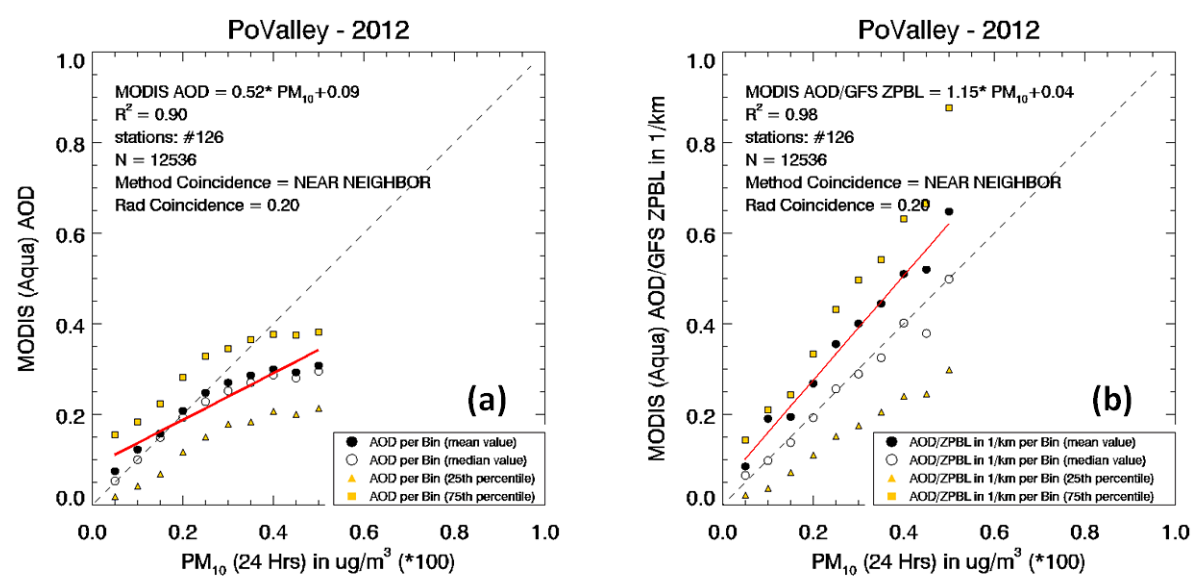

\section{ACPD}

$15,123-155,2015$

\section{High spatial resolution aerosol retrievals}

\section{B. Arvani et al.}

\section{Title Page}
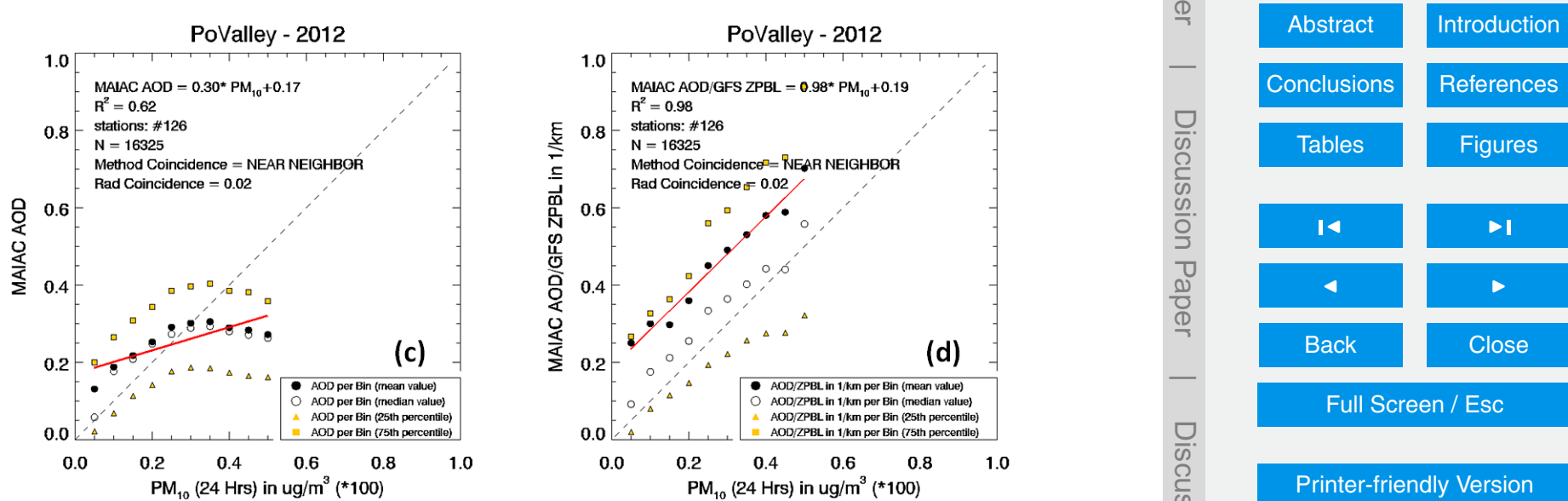

Printer-friendly Version

Figure 9. Bin scatter plots results for the Po valley domain, for the nearest neighbor approach. In the upper side of the panel, (a) and (b), the MYD04 results are shown. In the lower side, (c) and (d), the comparison with the MAIAC results are presented. 

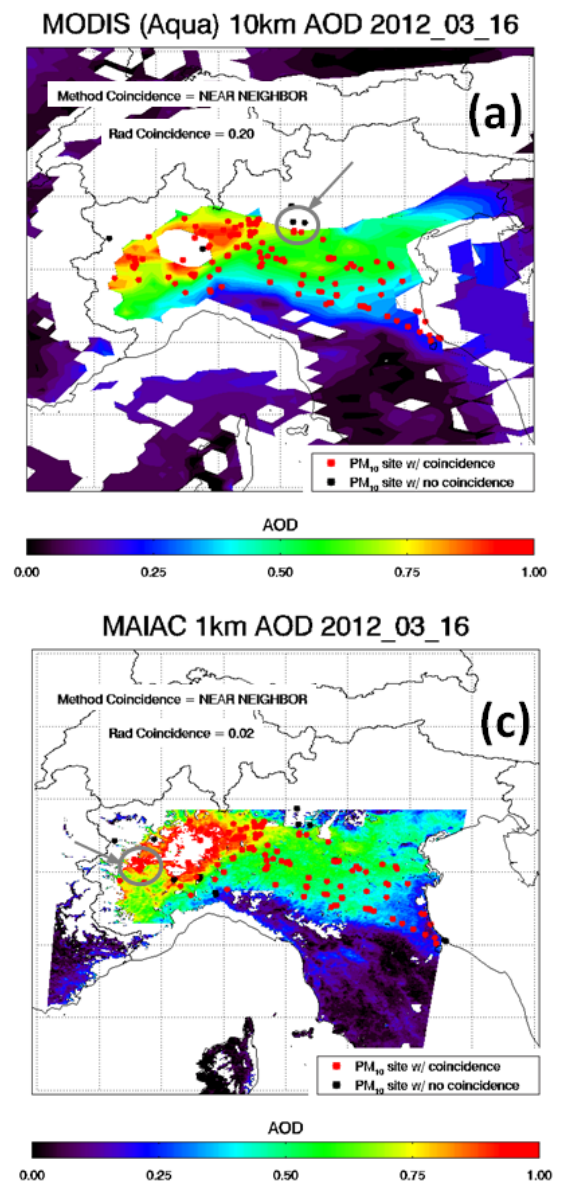

MODIS (Aqua) 10km AOD 2012_03_16
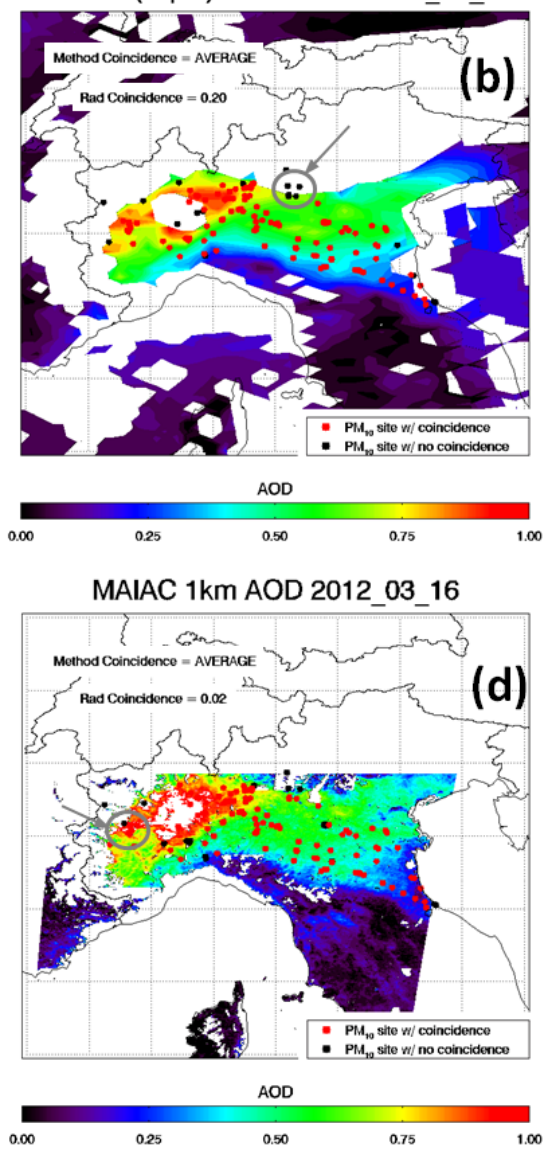

Figure 10. MYD04 $10 \mathrm{~km}$ (on the left) and MAIAC $1 \mathrm{~km}$ (on the right) AOD for 16 March 2012, for the two methods to find coincidences analyzed in this work. The dots mark locations of the ARPA $\mathrm{PM}_{10}$ ground station sites, where the red ones identify a coincidence site, while the black one a non-coincidence site.
ACPD

$15,123-155,2015$

\section{High spatial resolution aerosol retrievals}

B. Arvani et al.

\section{Title Page}

Abstract

Introduction

Conclusions

References

Tables

Figures

14

4

Back

Close

Full Screen / Esc

Printer-friendly Version

Interactive Discussion 

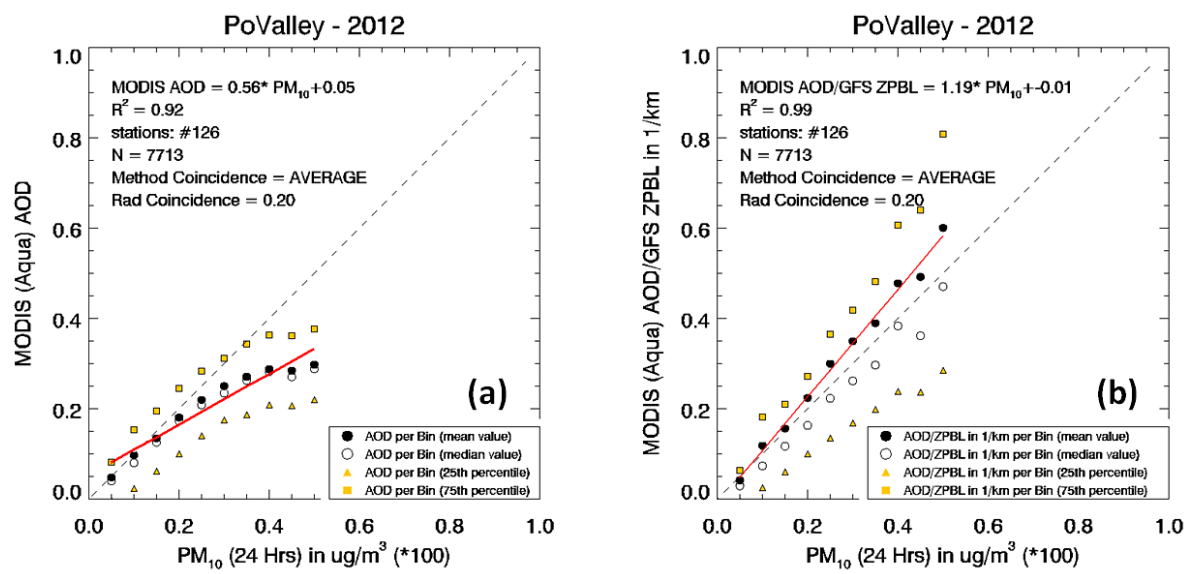

\section{ACPD}

15, 123-155, 2015

\section{High spatial resolution aerosol retrievals}

B. Arvani et al.
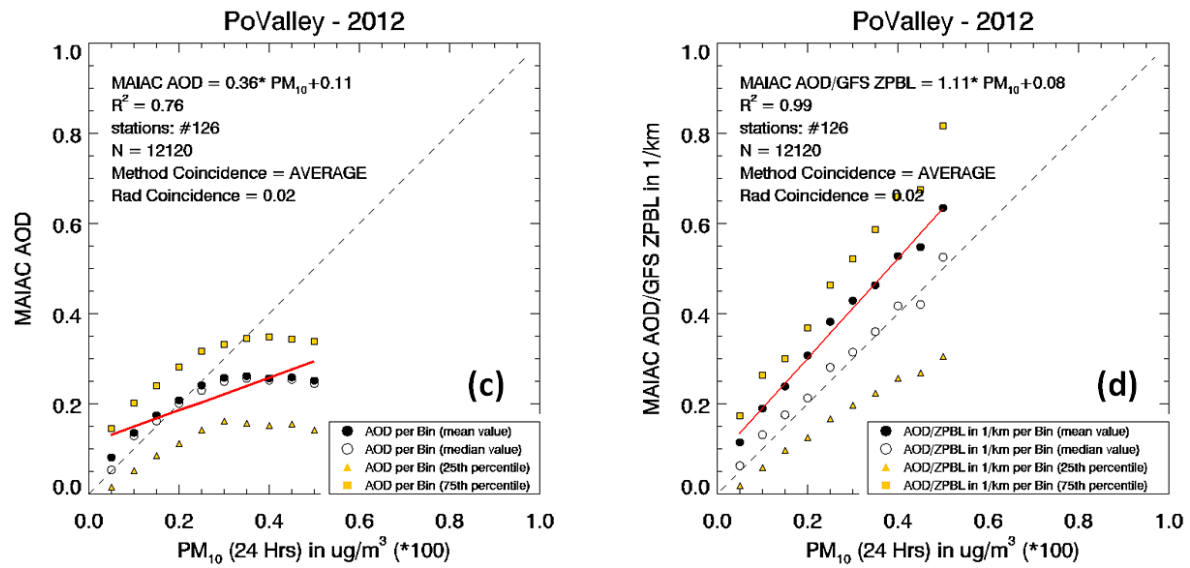

Title Page

Abstract

Introduction

Conclusions

References

Tables

Figures

14

4

Back

$>$

Full Screen / Esc

Printer-friendly Version

Interactive Discussion

Figure 11. In scatter plots results for the Po valley domain, for the average approach. In the upper side of the panel, (a) and (b), the MYD04 results are shown. In the lower side, (c) and (d), the comparison with the MAIAC results are presented. 

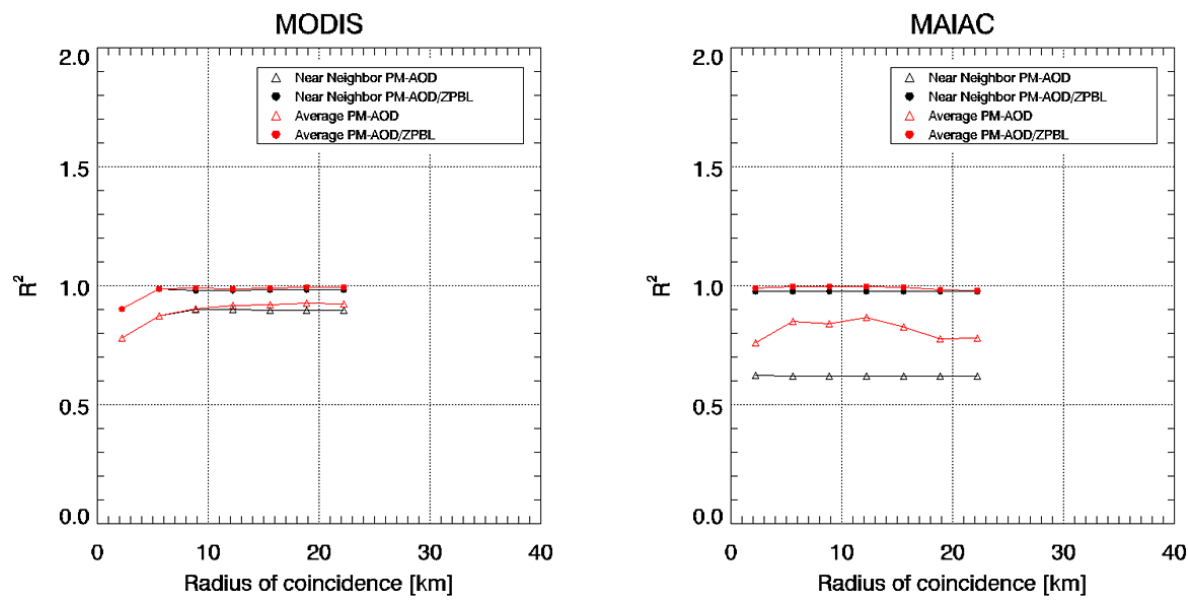

ACPD

15, 123-155, 2015

\section{High spatial resolution aerosol retrievals}

B. Arvani et al.

\section{Title Page}

\section{Abstract}

Introduction

Conclusions

References

Tables

Figures

14

Figure 12. Coefficient of determination $R^{2}$ dependence on different values of radius of coincidence, where on the left are reported the results obtained from MYD04 data sets and on the right the results obtained from MAIAC.

4

Back

$>$

\section{Full Screen / Esc}

Printer-friendly Version

Interactive Discussion 

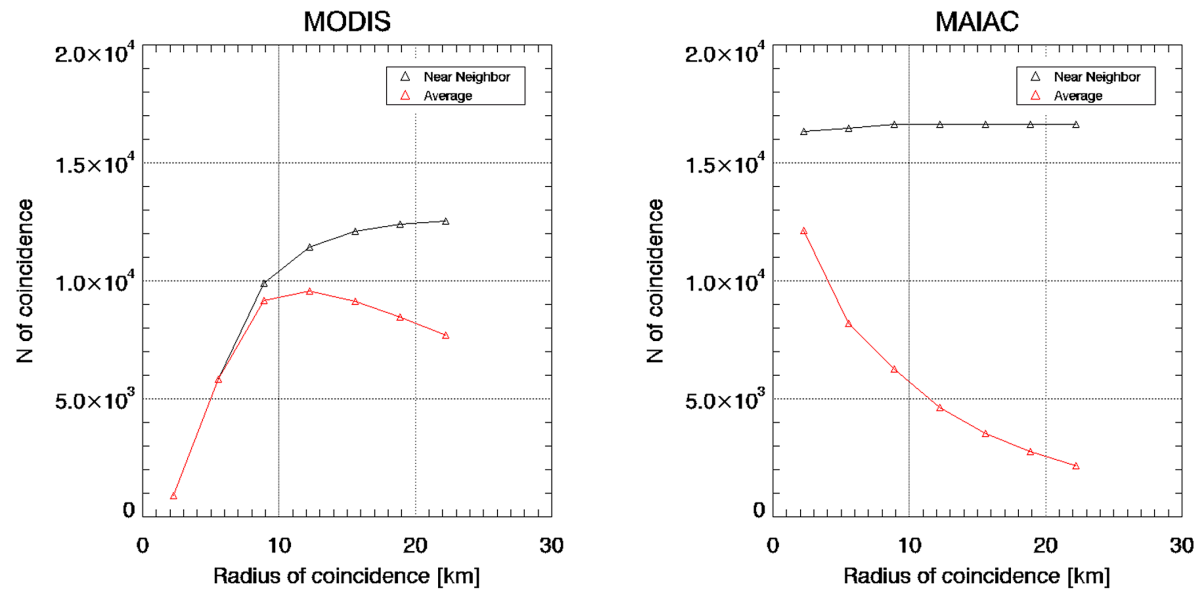

ACPD

15, 123-155, 2015

\section{High spatial} resolution aerosol retrievals

B. Arvani et al.

\section{Title Page}

\section{Abstract}

Introduction

Conclusions

References

Tables

Figures

14

Figure 13. Number of coincidence dependence on different values of radius of coincidence, where on the left are reported the results obtained from MYD04 data sets and on the right the results obtained from MAIAC.

4

Back

$>$

Close

Full Screen / Esc

Printer-friendly Version

Interactive Discussion 